Abstract THU0448 -Table 1. Mean MDHAQ scores in patients with primary OA or RA at 1st visit, and 1 or 2 years later

\begin{tabular}{|c|c|c|c|c|c|c|c|c|c|c|c|}
\hline \multirow{2}{*}{$\begin{array}{l}\text { Mean scores at... } \\
\text { Variable: }\end{array}$} & \multicolumn{3}{|c|}{ 1st visit } & \multicolumn{3}{|c|}{ 1-year later } & \multicolumn{3}{|c|}{ 2-years later } & \multicolumn{2}{|c|}{$P$ Change in OAvsRA } \\
\hline & $O A$ & RA & $\mathrm{P}$ & $\mathrm{OA}$ & RA & $\mathrm{P}$ & $O A$ & RA & $\mathrm{P}$ & 1 year & 2 years \\
\hline \# patients & 101 & 175 & & 101 & 175 & & 45 & 113 & & & \\
\hline RAPID3 (0-30) & 11.9 & 13.7 & 0.03 & 11.5 & 10.9 & 0.50 & 11.9 & 9.0 & 0.02 & 0.004 & 0.0004 \\
\hline Function (0-10) & 0.63 & 0.78 & 0.03 & 0.61 & 0.66 & 0.43 & 0.72 & 0.53 & 0.046 & 0.119 & 0.009 \\
\hline Pain (0-10) & 5.0 & 5.5 & 0.16 & 4.9 & 4.3 & 0.43 & 4.7 & 3.6 & 0.03 & 0.004 & 0.004 \\
\hline PATGL (0-10) & 4.8 & 5.6 & 0.01 & 4.6 & 4.4 & 0.54 & 4.9 & 3.7 & 0.009 & 0.005 & 0.0001 \\
\hline Fatigue $(0-10)$ & 3.9 & 4.9 & 0.008 & 3.7 & 4.0 & 0.43 & 3.6 & 4.0 & 0.41 & 0.073 & 0.359 \\
\hline Self-report painful JC & 12.0 & 15.4 & 0.014 & 9.5 & 11.7 & 0.10 & 11.9 & 10.2 & 0.35 & 0.415 & 0.035 \\
\hline
\end{tabular}

Abstract THU0439 - Table 1. Hypothesized and actual correlations for hypothesis testing

\begin{tabular}{|c|c|c|c|c|}
\hline \multirow[t]{2}{*}{ PCS total score } & \multicolumn{2}{|c|}{$\begin{array}{l}\text { Hypothesized } \\
\text { Correlations }\end{array}$} & \multirow{2}{*}{$\begin{array}{c}\begin{array}{c}\text { Actual } \\
\text { Correlation }\end{array} \\
\mathbf{R} \text { (p-value) }\end{array}$} & \multirow[t]{2}{*}{$\begin{array}{l}\text { Hypothesis } \\
\text { met }\end{array}$} \\
\hline & Magnitude & Direction & & \\
\hline \multicolumn{5}{|l|}{ Internal resource } \\
\hline $\begin{array}{l}\text { Pain self-efficacy } \\
\text { questionnaire }\end{array}$ & Moderate & - & -0.4186 ** & Yes \\
\hline \multicolumn{5}{|l|}{ Mental well-being } \\
\hline HADS & Strong & + & 0.5823 ** & Yes \\
\hline $\begin{array}{l}\text { SF-36 mental health } \\
\text { Physical well-being }\end{array}$ & Moderate & - & $-0.3323^{* *}$ & Yes \\
\hline WOMAC physical function & Moderate & + & $0.4767^{* *}$ & Yes \\
\hline WOMAC pain & Moderate & + & $0.4671 * *$ & Yes \\
\hline $\begin{array}{l}\text { SF-36 physical functioning } \\
\text { Social well-being }\end{array}$ & Moderate & - & -0.2632 ** & No \\
\hline $\begin{array}{l}\text { Lubben's social network } \\
\text { score }\end{array}$ & Weak & $+/-$ & -0.0486 & Yes \\
\hline
\end{tabular}

${ }^{* *} \mathrm{p}<0.001$; HADS: Hospital Anxiety and Depression Scale

Disclosure of Interests: Wei Jie Ong: None declared, Yu Heng Kwan: None declared, Julian Thumboo: None declared, Seng Jin Yeo: None declared, William Yeo: None declared, Ying Ying Leung Grant/research support from: Abbvie, Novartis, Speakers bureau: Abbvie and Novartis, Speakers bureau: Novartis

DOI: 10.1136/annrheumdis-2019-eular.4198

\section{THU0440 THE ASSOCIATION OF PLASMA FATTY ACIDS LEVELS WITH HAND AND KNEE OSTEOARTHRITIS}

Marieke Loef ${ }^{1}$, Andreea loan-Facsinay ${ }^{1}$, Dennis Mook ${ }^{2}$, Ko Willems van Dijk ${ }^{3}$, Renée de Mutsert ${ }^{2}$, Margreet Kloppenburg, ${ }^{1,2}$, Frits Rosendaal ${ }^{2}{ }^{1}{ }^{2}$ LUMC,

Rheumatology, Leiden, Netherlands; ${ }^{2}$ LUMC, Epidemiology, Leiden, Netherlands; ${ }^{3}$ LUMC, Human Genetics, Leiden, Netherlands

Background: Obesity is one of the most important risk factors for osteoarthritis $(\mathrm{OA})$. For long the association between obesity and $\mathrm{OA}$ was thought to be explained by increased mechanical loading. However, the role of systemic factors is increasingly recognized, especially in nonweightbearing joints. Obesity is strongly associated with increased levels of circulating fatty acids, which may result in lipotoxicity. However, our knowledge about the effect of different fatty acids on OA is sparse.

Objectives: To investigate the association of plasma saturated fatty acids (SFAs), monounsaturated fatty acid (MUFAs), polyunsaturated fatty acids (PUFAs), omega ( $\mathrm{n}-3$ and $\mathrm{n}-6$ PUFAs with clinically defined hand and knee OA.

Methods: In the population-based Netherlands Epidemiology of Obesity (NEO) study, a total of 6,671 middle-aged participants were recruited from the greater area of Leiden. Clinical hand and knee OA were defined by the ACR clinical classification criteria. Blood samples were obtained after an overnight fast and 150 minutes after consumption of a standardized liquid mixed meal containing $600 \mathrm{kCal}$, with $16 \%$ of energy (En\%) derived from protein, $50 \mathrm{En} \%$ from carbohydrates and $34 \mathrm{En} \%$ from fat. EDTA-plasma samples were used for a high-throughput proton nuclear magnetic resonance (NMR) metabolomics platform (Nightingale Health Ltd., Helsinki, Finland) to quantify 159 lipid and metabolite measures. For the present analyses the concentrations of fasting and postprandial total fatty acids, SFAs, MUFAs, PUFAs, $n-6$ PUFAs and $n-3$ PUFAs in $\mathrm{mmol} / \mathrm{l}$ were used. Since we are in a postprandial state most of the day, these samples were used for the primary analyses. All fatty acid concentrations were standardized (mean 0 , SD 1), to ensure a similar interpretation of the estimated effect. We excluded participants who reported to have inflammatory rheumatic disease or fibromyalgia, with missing physical examination, who were non-fasting at baseline, or reported using lipid-lowering medication. Logistic regression analyses were used to investigate the association between fatty acids and clinical $O A$ phenotypes. All analyses were stratified by sex and corrected for age, education, ethnicity and total body fat percentage. Data are presented as odds ratios (OR) with 95\% confidence intervals (Cl).

Results: In the current analysis 5,328 NEO participants were included, with a mean age of 56 years and $58 \%$ were women. Hand OA, knee $\mathrm{OA}$ and concurrent hand and knee OA were defined in $8 \%, 10 \%$ and $4 \%$ of participants, respectively. After correction for possible confounders, total fatty acids, SFA, total PUFA and omega-3 PUFA levels were positively associated with clinical hand $\mathrm{OA}$ in men, with $\mathrm{OR}(95 \% \mathrm{Cl})$ of $1.24(1.01 ; 1.53), 1.23(1.00-1.50), 1.26(1.00-1.58)$ and $1.24(1.01$ - 1.52), respectively. Although not significant, similar effect estimates were observed for men with concurrent hand and knee OA, but not for clinical knee $\mathrm{OA}$ alone. In women no associations were seen of any of the fatty acids with clinical hand or knee OA. Analyses of the association between fasting fatty acid levels and clinical hand and knee OA showed rather similar results, with slightly lowered ORs and wider confidence intervals.

Abstract THU0440 -Table 2.

\begin{tabular}{|c|c|c|c|c|}
\hline & & $\begin{array}{l}\text { Hand OA } \\
\text { OR (1956 Cl) }\end{array}$ & $\begin{array}{l}\text { Knee OA } \\
\text { OR (95\% CII) }\end{array}$ & $\begin{array}{l}\text { Hand and knee } O A \\
\text { OR }(95 \% \text { C C } 1)\end{array}$ \\
\hline & $\begin{array}{l}\text { Men } \\
\text { Women }\end{array}$ & $\begin{array}{l}1.24(1.01 ; 1.53) \\
1.05(0.85 ; 1.30)\end{array}$ & $\begin{array}{l}0.93(0.78 ; 1.12)\} \\
0.88(0.74 ; 1.05)\end{array}$ & $\begin{array}{l}1.21(0.76 ; 1.90) \\
0.93(0.61 ; 1.13)\end{array}$ \\
\hline & $\begin{array}{l}\text { Men } \\
\text { Women }\end{array}$ & $\begin{array}{l}1.23(1.00 ; 1.50) \\
1.05(0.84 ; 1.31)\end{array}$ & $\begin{array}{l}0.99(0.83 ; 1.1 .9) \\
0.86(0.72 ; 1.03)\end{array}$ & $\begin{array}{l}1.1 .9(0.80 ; 1.75) \\
0.76(0.56 ; 1.04)\end{array}$ \\
\hline & $\begin{array}{l}\text { Men } \\
\text { Women }\end{array}$ & $\begin{array}{l}1.20(0.96 ; 1.50) \\
0.98(0.80 ; 1.20)\end{array}$ & $\begin{array}{l}0.92(0.76 ; 1.12) \\
0.92(0.78 ; 1.08)\end{array}$ & $\begin{array}{l}1.12(0.64 ; 1.98) \\
0.81(0.60 ; 1.10)\end{array}$ \\
\hline & $\begin{array}{l}\text { Men } \\
\text { Women }\end{array}$ & $\begin{array}{l}1.26(1.000 .1 .58) \\
1.13(10.91 ; 1.41)\end{array}$ & $\begin{array}{l}0.90(0.74 ; 1.09) \\
0.88(0.73 ; 1.06)\end{array}$ & $\begin{array}{l}1.31(0.84 ; 2.204) \\
0.86(0.64 ; .1 .14)\end{array}$ \\
\hline & $\begin{array}{l}\text { Men } \\
\text { Women }\end{array}$ & $\begin{array}{l}1.24(1.01 ; 1.52) \\
1.13(10.90 ; 1.40)\end{array}$ & $\begin{array}{l}1.06(0.86 ; 1.29) \\
0.85(0.70 ; 1.04)\end{array}$ & $\begin{array}{l}1.24(0.83 ; 1.85) \\
0.96(0.74 ; 1.26)\end{array}$ \\
\hline & Men & $\begin{array}{l}1.24(0.088 .1 .56) \\
1.12(10.91 .199)\end{array}$ & 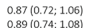 & $\begin{array}{l}1.29(0.85 ; .1 .97) \\
0.050 .064 .13)\end{array}$ \\
\hline
\end{tabular}

Conclusion: Quantitively measured plasma postprandial SFA and PUFA levels were significantly associated with hand $O A$ in men. In women no associations were found. Intriguingly, although SFA and omega-3 PUFAs are deemed to have opposing effects on inflammation, both were positively associated with hand OA. Future research is warranted to replicate the association and determine whether there is a causal role for plasma fatty acid levels in hand OA.

Disclosure of Interests: Marieke Loef Grant/research support from: Innovative Medicines Initiative Joint Undertaking under Grant Agreement $\mathrm{n}^{\circ}$ 115770, Andreea loan-Facsinay Shareholder of: Johnson \& Johnson, Dennis Mook Consultant for: Part-time clinical research consultant for MetaboIon, Inc., Ko Willems van Dijk: None declared, Renée de Mutsert: None declared, Margreet Kloppenburg Grant/research support from: Pfizer, IMIAPPROACH (Grant Agreement $n^{\circ}$ 115770), Consultant for: GlaxoSmithKline, Merck-Serono, Abbvie, Levicept, Pfizer, Frits Rosendaal: None declared

DOI: 10.1136/annrheumdis-2019-eular.1106 